\title{
Oleic acid induces down-regulation of the granulosa cell identity marker FOXL2, and up-regulation of the Sertoli cell marker SOX9 in bovine granulosa cells
}

\author{
Vengala Rao Yenuganti and Jens Vanselow ${ }^{*}$ (i)
}

\begin{abstract}
During negative energy balance, the concentration of different fatty acids, especially of oleic acid (OA) increases in the follicular fluid of cattle. Previously, we showed that OA induced morphological, physiological and molecular changes in cultured bovine granulosa cells. In our present study we analyzed effects of OA on the expression of markers for granulosa and Sertoli cell identity, FOXL2 and SOX9, respectively, in addition to effects on the FOXL2 regulated genes ESR2, FST, PTGS2 and PPARG. The results showed that OA down-regulated FOXL2, ESR2, FST and PPARG but up-regulated PTGS2 and SOX9. From these data we conclude that OA can compromise granulosa cell functionality and may initiate trans-differentiation processes in bovine granulosa cells. This novel mechanism may be causally involved in postpartum fertility problems of lactating dairy cows.
\end{abstract}

Keywords: Negative energy balance, PTGS2, ESR2, Cell identity

\section{Introduction}

High-yielding dairy cows suffer from negative energy balance after parturition [1, 2]. To meet their energy requirements in spite of low blood glucose levels lactating dairy cows mobilize fat from adipose tissue. Consequently, levels of free fatty acids like palmitic acid (PA, 16:0), stearic acid (SA, 18:0), oleic acid (OA, 18:1) and of $\beta$-hydroxybutyric acid increase in the plasma and follicular fluid [3, 4], which can cause decreased milk yield and increased vulnerability to infections, metabolic diseases and sub-fertility. Short-term fasting of cattle also increases the levels of different fatty acids in the follicular fluid and especially of OA [5]. In our previous study, we showed that $\mathrm{OA}$ at physiological concentrations remarkably affected the cell morphology, reduced the abundance of functionally important transcripts as FSHR, LHCGR, STAR, CYP11A1, HSD3B1 and CYP19A, and decreased the production of 17-beta estradiol (E2) in cultured bovine granulosa cells (GC). In contrast, the expression of CD36 and SLC27A1, encoding fatty-acid transporters was increased

\footnotetext{
* Correspondence: vanselow@fbn-dummerstorf.de

Institute of Reproductive Biology, Leibniz Institute for Farm Animal Biology (FBN), Wilhelm-Stahl-Allee 2, 18196 Dummerstorf, Germany
}

[6]. Sahmi et al. [7] showed that the transcription factor and GC identity marker FOXL2 is vital for higher activity of the CYP19A1 promoter P2 in bovine GC. So we hypothesized that OA may affect the expression of FOXL2 and thus the GC identity. FOXL2 is involved in the regulation of the Sertoli cell marker SOX9 in the ovary at early developmental and adult stages [8-12]. In adult mice the deletion of FOXL2 in GC increases the expression of SOX9 and development of seminiferous tubule-like structures in the ovary [11]. Also the deletion of estrogen receptors or low levels of estrogen resulted in a similar phenotype of GC [12-14], thus demonstrating that the expression of SOX9 in ovaries is normally suppressed via ESR2 (estrogen receptor 2) and E2 along with FOXL2. FOXL2 also positively regulates the expression of ESR2, $P P A R G$ and FST, whereas it negatively regulates the expression of PTGS2 [12, 15, 16]. These genes are essentially involved in normal GC function [17-21]. SOX9 is a very early and permanently expressed marker of Sertoli cells [22]. Loss- and gain-of-function studies revealed that SOX9 is required for Sertoli cell differentiation. Deletion of SOX9 in XY gonads leads to male-to-female sex reversal and misexpression in $\mathrm{XX}$ mice to female-to-male sex 
reversal $[23,24]$, thus demonstrating that $S O X 9$ plays an essential role during testis differentiation processes [2528]. On the other hand, the loss of the SRY-dependent SOX9 inducibility in bipotential gonadal cells is the earliest sign of pre-granulosa cell differentiation in XX gonads [29].

During the present study we analysed effects of $\mathrm{OA}$ in cultured bovine GC on FOXL2 and SOX9, which are essentially involved in the maintenance of granulosa and Sertoli cell identity, respectively. In addition, we also studied effects of OA on other functionally important genes that are regulated by FOXL2 like ESR2, PPARG, FST and PTGS2.

\section{Materials and methods}

\section{Serum free bovine granulosa cell culture}

As an experimental model GC were aspirated from small to medium sized follicles $(2-6 \mathrm{~mm})$ from slaughterhouse material, plated on collagen coated 24-well plates with $1.25 \times 10^{5}$ viable cells and cultured in serumfree $\alpha$-MEM containing L-Glutamin $(2 \mathrm{mM})$, sodium bicarbonate $(0.084 \%)$, BSA $(0.1 \%)$, HEPES $(20 \mathrm{mM})$, sodium selenite $(4 \mathrm{ng} / \mathrm{ml})$, transferrin $(5 \mu \mathrm{g} / \mathrm{ml})$, insulin $(10 \mathrm{ng} / \mathrm{ml})$, non-essential amino acids (1 mM), penicillin (100 IU) and streptomycin $(0.1 \mathrm{mg} / \mathrm{ml}$; Biochrom, Berlin, Germany) with FSH and IGF1 stimulation and androstenedione $(2 \mu \mathrm{M})$ supplementation (Sigma Aldrich, Steinheim, Germany) at $37{ }^{\circ} \mathrm{C}$ in a $5 \% \mathrm{CO}_{2}$ atmosphere according to our previous studies [6, 30, 31]. Media were replaced with fresh media including all respective supplements every other day. OA was added from the first change of media (i.e. after 2 days in culture) to the end of culture after 8 days. The amount of added OA (dissolved in ethanol as described previously [6]) in all the experiments was $400 \mu \mathrm{M}$, which is in the range of physiological concentrations after fasting [5] and reproducibly affected hormone production and gene expression of cultured GC [6]. As a vehicle control, cells were treated with equal volumes of ethanol corresponding to OA treatment.

RNA isolation, CDNA synthesis and real- time PCR RNA was isolated with the Nucleo Spin ${ }^{\circ}$ RNA II Kit according to the manufacturer's instructions and quantified with a NanoDrop1000 Spectrophotometer (Thermo Scientific, Bonn, Germany). The cDNA was prepared by using the SensiFAST cDNA Synthesis Kit (Bioline, Luckenwalde, Germany) from 200 ng RNA as per the manufacture's protocol. Transcript abundance of FOXL2, SOX9, ESR2, FST, PPARG and PTGS2 was analyzed as described in our previous studies $[6,31]$ by real time PCR with SensiFast SYBR No-ROX (Bioline) and gene-specific primers (listed in Table 1) in a Light Cycler 96 instrument (Roche,Mannheim, Germany). The abundance of all transcripts was calculated relative to transcripts of the TATA-binding protein (TBP) as an appropriate housekeeping gene [32].

\section{Isolation of soluble cell extracts and immunoblotting}

Isolation of soluble cell extracts and immunoblotting for detection of FOXL2 and SOX9 proteins, and of GAPDH as a loading control, was done as described previously [31]. Primary antibodies were from Thermo Fisher Scientific, Dreieich, Germany (FOXL2, Cat\# PA1-31950) or Cell Signaling Technology, Frankfurt/main, Germany (SOX9, Cat\# CST 7074, GAPDH, Cat\# CST 3683), secondary antibodies from Cell Signaling Technology (anti-rabbit IgG, HRP-linked Antibody, Cat\# CST) or Santa Cruz, Heidelberg, Germany (donkey anti-goat IgG-HRP, Cat\# sc-2020).

Table 1 List of primers used for transcript quantification by qPCR

\begin{tabular}{|c|c|c|c|}
\hline Name & Sequence & Size (bp) & NCBI accession no. \\
\hline ESR2 Forward & GGTCAATCCATCCTACCCCT & 264 & NM_174051.3 \\
\hline ESR2 Reverse & TTCACGCCAAGGACTCTTTT & & \\
\hline FOXL2 Forward & AGCCAAGTTCCCGTTCTACG & 140 & NM_001031750.1 \\
\hline FOXL2 Reverse & GGTCCAGCGTCCAGTAGTTG & & \\
\hline FST Forward & GCACTGGCCGCCTGAGCACCT & 191 & NM_175801 \\
\hline FST Reverse & TGGGGCACAGACGCAGCGGG & & \\
\hline PPARG forward & TATCCCCGGCTITGTGAACC & 288 & NM_181024.2 \\
\hline PPARG Reverse & GGGCGGTCTCCACTGAGAAT & & \\
\hline PTGS2 Forward & TACAGCACTTGAGTGGCTATCAC & 317 & NM_174445 \\
\hline PTGS2 Reverse & CTGGTCAATTGAAGCCTITGATAC & & \\
\hline SOX9 Forward & ACCTGGAACTTCAGTGGCG & 147 & XM_010816647.1 \\
\hline SOX9 Reverse & CCAAGTAGGGGAAGGCGAAT & & \\
\hline TBP Forward & GCCTTGTGCTTACCCACCAACAGTTC & 200 & NM_001075742.1 \\
\hline TBP Reverse & TGTCTTCCTGAAACCCTTCAGAATAGGG & & \\
\hline
\end{tabular}




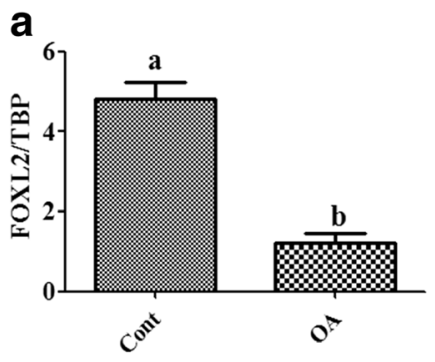

b

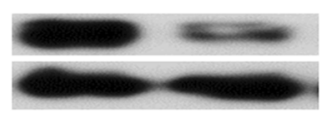

Cont

OA
FOXL2

GAPDH

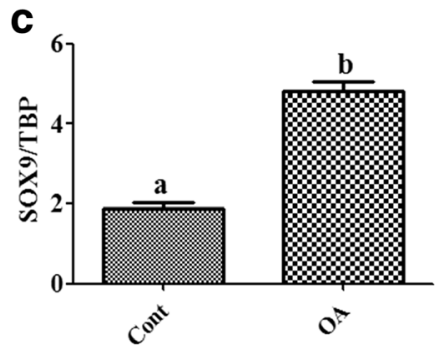

d

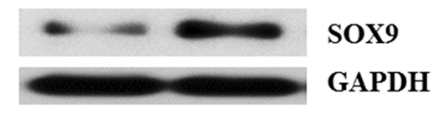

Cont OA

Fig. 1 Effects of oleic acid on the expression of the granulosa cell marker FOXL2 and the Sertoli cell marker SOX9 in cultured granulosa cells. Oleic acid (OA) induced down-regulation of FOXL2 mRNA and protein abundance (a and b), respectively, and up-regulation of SOX9 mRNA and protein, respectively (c and $\mathbf{d}$ ). GAPDH protein is shown as a loading control. Different letters indicate significant differences between treatment groups (mean transcript abundance relative to TBP \pm standard error; different letters indicate significantly different means if $P<0.05$, unpaired t-test from three independent experiments). Cont denotes vehicle control and OA denotes oleic acid treatment

\section{Statistical analysis}

Data of all experiments were analysed by paired t-test using the GraphPad prism 5.0 software. All experiments were conducted three times independently.

\section{Results}

The results showed that OA clearly down regulated the transcript abundance and protein levels of FOXL2, but up regulated those of $S O X 9$ (Fig. 1). As OA inhibited FOXL2 mRNA and protein levels, we analyzed the effects of $\mathrm{OA}$ on the expression of genes that are involved in different functions of GC and are regulated by FOXL2 as FST, ESR2, PTGS2 and PPARG [12]. The results showed that OA significantly down regulated the expression of ESR2, PPARG and FST as compared with vehicle treated controls, whereas PTGS2 was increased (Fig. 2).

\section{Discussion}

In the present study OA markedly reduced the levels of the transcription factors FOXL2 and ESR2, and increased the expression of SOX9. It is a very well established fact that FOXL2 is involved in maintaining the identity of
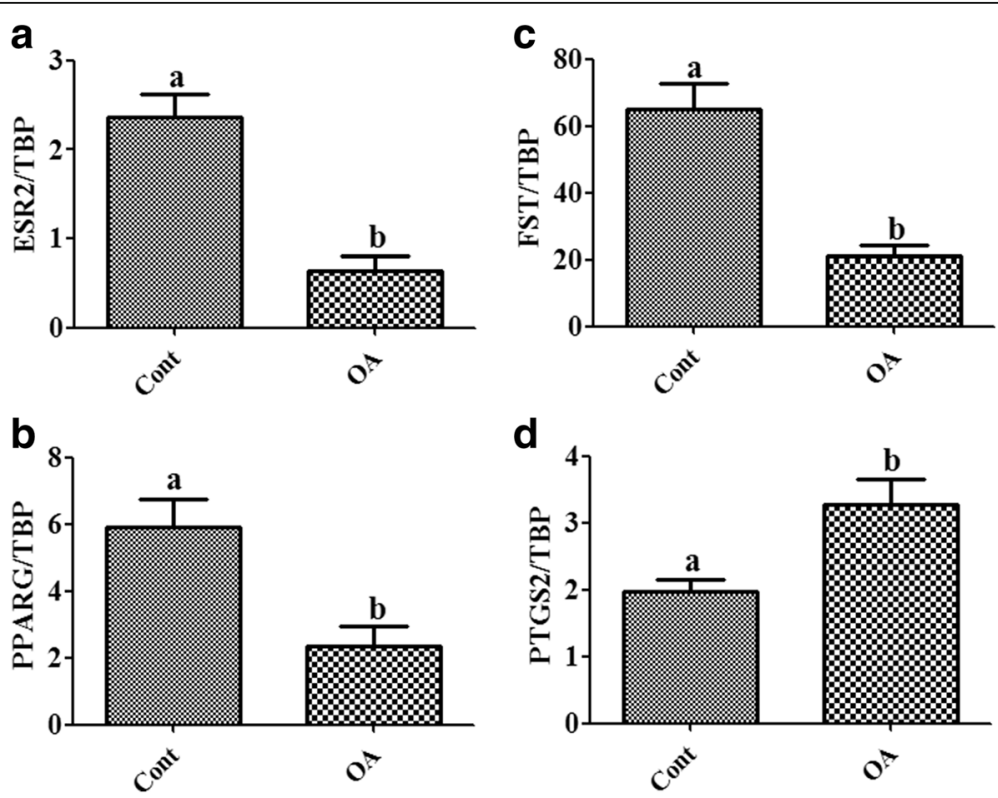

Fig. 2 Effect of oleic acid on the expression of FOXL2 regulated genes. (a, b, c and $\mathbf{d}$ ) OA induced regulation of ESR2, PPARG, FST and PTGS2 transcript abundance levels. Different letters indicate significant differences between treatment groups (mean transcript abundance relative to $\mathrm{TBP} \pm$ standard error; different letters indicate significantly different means if $P<0.05$, unpaired t-test from three independent experiments). Cont denotes vehicle control and OA denotes oleic acid treatment 
GC [12]. The deletion of FOXL2 in GC of adult mice resulted in the development of seminiferous tubule-like structures along with the expression of Sertoli-cell marker genes in the ovary [11]. Georges et al. [12] showed that knockdown of FOXL2 or ESR2 leads to a rise of SOX9 levels and in case of a knockdown of both genes, SOX9 levels became even more effectively upregulated. The same study also showed that knockdown of ESR1 has no clear effect on SOX9 repression following E2 treatment, but ESR2 knockdown resulted in an increase of SOX9 expression, whereas SOX9 expression was markedly increased in the absence of FOXL2. Thus, FOXL2 and ESR2/E2 repress SOX9 expression in follicular GC independent of each other [12]. In addition to this, it has been shown that FOXL2 regulates many genes like FST, PTGES2 and PPARG [12]. Our results showed that OA down regulated the expression of FST and PPARG along with that of FOXL2. The expression of FST in the ovary and GCs is regulated by FOXL2 $[8,16]$. Knockdown of FOXL2 leads to decreased expression of PTGS2 and PPARG in murine primary GC [12]. Our results showed that OA induced down-regulation of PPARG along with FOXL2 but not of PTGS2, which was increased by OA treatment. Kim et al. [15] showed that FOXL2 represses the expression of PTGS2, which would be in line with our data. This suggests that OA may up-regulate SOX9 expression by reducing the levels of FOXL2, ESR2 and of E2. The data of our present study demonstrate that the expression of FOXL2, ESR2, PPARG, and FST was clearly decreased. In contrast, the expression of PTGS2 and in particular of SOX9 was increased by OA. Accordingly, we propose that OA induces the Sertoli cell marker SOX9 in GC eventually leading to a partial loss of GC identity, which may severely compromise GC's functionality.

\section{Conclusions}

Our data suggest that (i) OA treatment reduced the expression of FOXL2. (ii) The inhibition of FOXL2 expression in turn may lead to the down-regulation of ESR2, FST and PPARG. (iii) The low levels of FOXL2, ESR2 and of E2 may overcome transcriptional suppression of the Sertoli cell marker SOX9 and thus induce trans-differentiation-like processes, which would severely compromise GC functionality. This novel observation could partly explain the negative effects of increased OA concentrations on postpartum fertility in dairy cows.

\footnotetext{
Abbreviations

CYP19A1: Cytochrome P450, family 19, subfamily A, polypeptide 1; E2: 17-beta estradiol; ESR2: Estrogen receptor 2; FOXL2: Forkhead box protein L2; FSH: Folliclestimulating hormone; FST: Follistatin; GAPDH: Glyceraldehyde-3-phosphate dehydrogenase; GC: Granulosa cells; IGF-1: Insulin-like growth factor 1; PPARG: Peroxisome proliferator-activated receptor gamma; PTGES2: Prostaglandin E synthase 2; SOX9: SRY (sex determining region Y)-box 9; TBP: TATA-binding protein
}

\section{Acknowledgments}

We thank Veronica Schreiter, Maren Anders, GesineKrüger, Swanhild Rodewald, Ursula Antkewitz and Christian Plinski for excellent technical support during experiments. The publication of this article was funded by the Open Access Fund of the Leibniz Association and the Open Access Fund of the Leibniz Institute for Farm Animal Biology (FBN).

\section{Funding}

This study was supported by the core budget of the Leibniz Institute for Farm Animals (FBN).

\section{Availability of data and materials}

The datasets used and/or analyzed during the current study are available from the corresponding author on reasonable request.

\section{Authors' contributions}

VRY and JV conceived and designed the experiments, and wrote the paper. VRY performed the experiments. Both authors read and approved the final manuscript.

Ethics approval and consent to participate

Not applicable.

\section{Consent for publication}

Not applicable.

\section{Competing interests}

The authors declare that they have no competing interests.

Received: 12 May 2017 Accepted: 20 July 2017

Published online: 26 July 2017

References

1. Beam SW, Butler WR. Effects of energy balance on follicular development and first ovulation in postpartum dairy cows. J Reprod Fertil Suppl. 1999:54:411-24.

2. Opsomer G, Grohn YT, Hertl J, Coryn M. Deluyker H, de KA: risk factors for post partum ovarian dysfunction in high producing dairy cows in Belgium: a field study. Theriogenology. 2000;53:841-57.

3. Leroy JL, Vanholder T, Mateusen B, Christophe A, Opsomer G, De KA, Genicot G, Van SA. Non-esterified fatty acids in follicular fluid of dairy cows and their effect on developmental capacity of bovine oocytes in vitro. Reproduction. 2005;130:485-95.

4. Rukkwamsuk T, Geelen MJ, Kruip TA, Wensing T. Interrelation of fatty acid composition in adipose tissue, serum, and liver of dairy cows during the development of fatty liver postpartum. J Dairy Sci. 2000;83:52-9.

5. Aardema $H$, Lolicato $F$, van de Lest $C H$, Brouwers JF, Vaandrager $A B$, van Tol $H T$, Roelen BA, Vos PL, Helms JB, Gadella BM. Bovine cumulus cells protect maturing oocytes from increased fatty acid levels by massive intracellular lipid storage. Biol Reprod. 2013;88:164.

6. Yenuganti VR, Viergutz T, Vanselow J. Oleic acid induces specific alterations in the morphology, gene expression and steroid hormone production of cultured bovine granulosa cells. Gen Comp Endocrinol. 2016;232:134-44.

7. Sahmi F, Nicola ES, Zamberlam GO, Goncalves PD, Vanselow J, Price CA. Factors regulating the bovine, caprine, rat and human ovarian aromatase promoters in a bovine granulosa cell model. Gen Comp Endocrinol. 2014;200:10-7.

8. Ottolenghi C, Omari S, Garcia-Ortiz JE, Uda M, Crisponi L, Forabosco A, Pilia G, Schlessinger D. Foxl2 is required for commitment to ovary differentiation. Hum Mol Genet. 2005;14:2053-62.

9. Ottolenghi C, Pelosi E, Tran J, Colombino M, Douglass E, Nedorezov T, Cao A, Forabosco A, Schlessinger D. Loss of Wnt4 and Foxl2 leads to female-to-male sex reversal extending to germ cells. Hum Mol Genet. 2007;16:2795-804

10. Garcia-Ortiz JE, Pelosi E, Omari S, Nedorezov T, Piao Y, Karmazin J, Uda M, Cao A, Cole SW, Forabosco A, et al. Foxl2 functions in sex determination and histogenesis throughout mouse ovary development. BMC Dev Biol. 2009;9:36. doi:10.1186/1471-213X-9-36:36-39.

11. Uhlenhaut NH, Jakob S, Anlag K, Eisenberger T, Sekido R, Kress J, Treier AC, Klugmann C, Klasen C, Holter $\mathrm{Nl}$, et al. Somatic sex reprogramming of adult ovaries to testes by FOXL2 ablation. Cell. 2009;139:1130-42. 
12. Georges A, L'Hote D, Todeschini AL, Auguste A, Legois B, Zider A, Veitia RA. The transcription factor FOXL2 mobilizes estrogen signaling to maintain the identity of ovarian granulosa cells. elife. 2014;3. doi:10.7554/eLife.04207:10.

13. Dupont S, Krust A, Gansmuller A, Dierich A, Chambon P, Mark M. Effect of single and compound knockouts of estrogen receptors alpha (ERalpha) and beta (ERbeta) on mouse reproductive phenotypes. Development. 2000;127:4277-91.

14. Fisher $C R$, Graves KH, Parlow AF, Simpson ER. Characterization of mice deficient in aromatase (ArKO) because of targeted disruption of the cyp19 gene. Proc Natl Acad Sci U S A. 1998:95:6965-70.

15. Kim SY, Weiss J, Tong M, Laronda MM, Lee EJ, Jameson JL. Foxl2, a forkhead transcription factor, modulates nonclassical activity of the estrogen receptor-alpha. Endocrinology. 2009;150:5085-93.

16. Cheng JC, Chang HM, Qiu X, Fang L, Leung PC. FOXL2-induced follistatin attenuates activin A-stimulated cell proliferation in human granulosa cell tumors. Biochem Biophys Res Commun. 2014;443:537-42.

17. Sirois J. Induction of prostaglandin endoperoxide synthase-2 by human chorionic gonadotropin in bovine preovulatory follicles in vivo. Endocrinology. 1994;135:841-8.

18. Glister C, Satchell L, Knight PG. Granulosal and thecal expression of bone morphogenetic protein- and activin-binding protein mRNA transcripts during bovine follicle development and factors modulating their expression in vitro. Reproduction. 2011;142:581-91.

19. Rosenfeld CS, Yuan X, Manikkam M, Calder MD, Garverick HA, Lubahn DB. Cloning, sequencing, and localization of bovine estrogen receptor-beta within the ovarian follicle. Biol Reprod. 1999:60:691-7.

20. Froment P, Fabre S, Dupont J, Pisselet C, Chesneau D, Staels B, Monget P. Expression and functional role of peroxisome proliferator-activated receptorgamma in ovarian folliculogenesis in the sheep. Biol Reprod. 2003;69:1665-74.

21. Zhang H, Li Q, Lin H, Yang Q, Wang H, Zhu C. Role of PPARgamma and its gonadotrophic regulation in rat ovarian granulosa cells in vitro. Neuro Endocrinol Lett. 2007;28:289-94.

22. Morais da Silva S, Hacker A, Harley V, Goodfellow P, Swain A, Lovell-Badge R: Sox9 expression during gonadal development implies a conserved role for the gene in testis differentiation in mammals and birds. Nat Genet. 1996;14:62-68

23. Jakob S, Lovell-Badge R. Sex determination and the control of Sox 9 expression in mammals. FEBS J. 2011;278:1002-9.

24. Wilhelm D, Palmer S, Koopman P. Sex determination and gonadal development in mammals. Physiol Rev. 2007;87:1-28.

25. Kent J, Wheatley SC, Andrews JE, Sinclair AH, Koopman P. A male-specific role for SOX9 in vertebrate sex determination. Development. 1996;122:2813-22.

26. Chaboissier MC, Kobayashi A, Vidal VI, Lutzkendorf S, van de Kant HJ, Wegner M, De Rooij DG, Behringer RR, Schedl A. Functional analysis of Sox8 and Sox9 during sex determination in the mouse. Development. 2004;131:1891-901.

27. Barrionuevo F, Bagheri-Fam S, Klattig J, Kist R, Taketo MM, Englert C, Scherer G. Homozygous inactivation of Sox 9 causes complete XY sex reversal in mice. Biol Reprod. 2006;74:195-201.

28. Vidal VP, Chaboissier MC, De Rooij DG, Schedl A. Sox9 induces testis development in XX transgenic mice. Nat Genet. 2001;28:216-7.

29. Harikae K, Miura K, Shinomura M, Matoba S, Hiramatsu R, Tsunekawa N, Kanai-Azuma M, Kurohmaru M, Morohashi K, Kanai Y. Heterogeneity in sexual bipotentiality and plasticity of granulosa cells in developing mouse ovaries. J Cell Sci. 2013;126:2834-44.

30. Baufeld A, Vanselow J. Increasing cell plating density mimics an early post-LH stage in cultured bovine granulosa cells. Cell Tissue Res. 2013;354:869-80.

31. Yenuganti VR, Vanselow J. Cultured bovine granulosa cells rapidly lose important features of their identity and functionality, but partially recover under long term culture conditions. Cell \& Tissue Research. 2017.

32. Baddela VS, Baufeld A, Yenuganti VR, Vanselow J, Singh D. Suitable housekeeping genes for normalization of transcript abundance analysis by real-time RT-PCR in cultured bovine granulosa cells during hypoxia and differential cell plating density. Reprod Biol Endocrinol. 2014;12:118.

\section{Submit your next manuscript to BioMed Central and we will help you at every step:}

- We accept pre-submission inquiries

- Our selector tool helps you to find the most relevant journal

- We provide round the clock customer support

- Convenient online submission

- Thorough peer review

- Inclusion in PubMed and all major indexing services

- Maximum visibility for your research

Submit your manuscript at www.biomedcentral.com/submit
C Biomed Central 